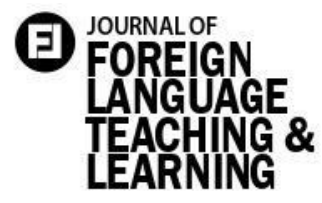

Volume 3, No. 2, 2018

Titis Wisnu Wijaya

earned his Bachelor Degree on

2012 and Master Degree on

2015. For the next years, he

joined Universitas

Muhammadiyah Yogyakarta as

an English lecturer at

Information Technology

Department. Now, his expertise and interests are in educational technology and English

education.

\section{The Effectiveness of Songs for Teaching Speaking}

\author{
Titis Wisnu Wijaya \\ Universitas Muhammadiyah Yogyakarta \\ titiswisnuwijaya@umy.ac.id \\ DOI: https://doi.org/10.18196/ftl.3231
}

\begin{abstract}
The primary motive for comprehending language is to create a communication. Speaking becomes a difficult thing to do for Indonesian learner when the learner wants to increase the speaking ability to the learner. Most learners are good in theory, yet bad in practice. Whereas speaking is the purpose of learning English. In this case, innovation in speaking skill must be innovative. Teaching speaking ability is not only delivering the material but also giving something different way to make learner interested. The research subject was the fourth-semester students in the academic year of 2013/2014. The students would be in two classes, i.e., the experimental and control group. The classes started with pre-test. The post-test fourth-semester in the last meeting after treatment. The researcher obtained the data from a speaking test and continued to analyze by inferential analysis. The research findings showed that the research had a gap in the students' speaking ability in the experimental group and the control group. From the data analysis, the scores in experimental and the control group increased.

Moreover, the increase in the experimental group was better than the control group. In the experimental group has three categories, i.e., good (2 students), fair (18 students), and poor (1 student). Post-test mean (17.47) was higher than the pre-test (10.19). The control group had three different categories, i.e., fair (5 students), poor (12 students), and very poor (3 students). Post-test mean (13.85) was higher than the pre-test (10.05). The data showed that post-test mean in the experimental group (17.47) was higher than the post-test mean in the control group (13.85). Therefore, the hypothesis "It has a high score in learning to speak using a song for students in the experimental group" was accepted.
\end{abstract}

Keywords: Songs, Teaching Speaking, Speaking Ability 


\section{Background of the Study}

Students' difficulties in speaking are visible from their product. The challenges are related to their speaking ability. The students might have fewer vocabularies to arrange sentences to speak. The other challenge comes from the lack of knowledge in mastering grammar. Those difficulties may emerge due to the differences between Indonesian and English.

Speaking is an essential skill to communicate. Cameron (2001) states that speaking is the use of language to indicate meaning to the others can make feeling ( $\mathrm{p}$. 40). Speaking is a production in using the language. Speaking also has another purpose that is an activity to use the language to communicate among members in society as a manifestation of one's language competence.

The common speaking issues are profound experiences, lacking selfconfidence, not being fluent, having little motivation, etc. The students' ability is essential for their speaking skill. In the case, the students require to overcome their speaking problem so that they will get excellent speaking achievement.

\section{Speaking Ability}

Urrutia and Vega (2010) find that most students consider speaking as the most difficult ability to learn. Also, the researchers saw merely few the students spoke English during the class.

Also, Nunan (2003) states that speaking consists of making systematic verbal expressions to bring sense (p. 48). First, speaking must be listened. It has temporary and prompt acceptance. Listening to others has stress, rhythm, and intonation. It should be intermediate feedback for direct communication. In the speaking activity, the speaker must be able to plan and edit channel.

According to Luoma (2008), to develop students' communicative in speaking, a facilitator can combine language input, structured output, and communicative output (p. 87).

First, language input comes from teacher talk, listening activities, reading texts, and the language heard. It gives students the material need to produce language.

Second, structured output focuses on correct form. In this part, students have options to response, yet all options require them to apply the structure that the teacher has already presented. It is designed to make students comfortable producing language items introduced, some while in combination with learned items. The teacher uses 
structured output exercises as a transition between the presentation stage and the practice stage of a lesson plan.

Third, the communicative output mentions that the students' purpose is to complete a task. Students may take the language that the teacher has just presented, but they also may know and draw on vocabulary, grammar, and communication strategies. In this part, the success criterion is whether the student gets the message across. The researcher concludes that speaking ability consists of linguistic performance and linguistic competence. That is the ability to manage meaningful words and sounds.

\section{The Speaking Interest}

As a social creature, human always communicates to others. It is a process of interchange of interactions, i.e., telling information, asking help for the needs, etc. It implies that speaking action has a significant role in human life.

In Urrutia and Vega (2010) research study, speaking is the most challenging skill to develop. Students usually present a lack of vocabulary and shyness. Thus, the researcher can measure students' speaking ability. Speaking ability can be measured not only from the performance but also, from their competence in language use.
The language purpose is communication, and the context of speaking objective is to promote communicative efficiency. It is essential to master writing, speaking, listening, and reading, but this research will focus on "speaking."

\section{Teaching Speaking}

Speaking English is neither an easy nor a fast process to learn. The facilitator should have a technique to increase student' speaking skill. Teaching speaking is not merely asking the student to speak up. Nunan (1991) states that speaking is the ways of how to deliver information and express idea (p. 40). The classroom is one of venue to children can increase linguistic competence.

Furthermore, speaking requires that learners not only comprehend how to gain a specific point of language, e.g., grammar, pronunciation or vocabulary but also, they must understand the way to produce the language

Speaking is a productive oral skill. Speaking in a foreign language is a complex effort which implicates adopting all the different language levels. The researcher needs to try several strategies for teaching speaking that can help language learners to gain speaking practice speaking (Nunan, 2003, p. 64). 


\section{Evaluating Speaking}

Hughes (2003) gives an extensive explanation summarized into five factors that should be involved in assessing speaking ability (pp. 131-133). Those are as follows; (1) Accent contains a vowel, segmental feature, and intonation pattern. The listener should apply it correctly. (2) Grammar is the role in spoken language and written language. To get a good result in speaking ability, learners should obey the rules of grammar. In writing, learners can also find the grammar role in pronunciation, morphology, and syntax. (3) Vocabulary is one of the linguistics factors in which the words number make up vocabulary. It is essential because the speaker cannot speak more if he or she has a limited vocabulary. Hornby (1974) defines vocabulary is a row of words applied in communication (p. 979). If learner master many vocabularies, it will be convenient to show ideas. (4) Fluency, a good criterion in speaking English well and fluently. Speaking fluently here means the speed of speaking. However, speaking fast does not always mean speaking correctly. Someone can be said fluent in speaking if he or she can say the words fluently with a proper grammar with high speed. English fluency, of course, makes the people communicate their ideas, thought, and feeling quickly in any situations.

\section{Songs in Language Teaching}

The essential part for learners is to choose the material. Song has great value among the materials used in the teaching-learning process. Song should be utilized as an effective teaching tool and it plays an essential part for psychological and emotive youth development (Rukholm, 2015, p. 178). Supporting learner to improve their intelligence, according to Simpson (2000), linguistic knowledge and musical intelligence have advantage one another by having wellplanned teaching-learning (p. 40).

Revealing students to text multeity and genres that contain multiple supposition as sound may not entertain them. Yet in the teaching learning process, facilitator help students to know themselves as benefactor who are led by inquiry, inspired by curiosity, and steadily reimagining the treatment from recent perspective (Carlson 2010, p. 70). First, song makes relaxing and entertaining the classroom e in which learners more open to studying. Second, song in the classroom has a cheerful way to learn English. Song is one of media that worthwhile to apply. The facilitator can explain grammatical with lyric of songs for it is easier to clarify in English article.

In conclusion, motivation is an essential part of learning, and creative idea in teaching is the way to develop learning motivation. 
Consequently, English popular songs applied in the study center as a motivational factor.

\section{Songs provide opportunities for real language use}

Sharpe (2001) believes that song sets a chance in language use in a fun way (p. 56). Young children are often singing and playing with rhymes and shortly imitate the sound.

The significant elements of music are melody and lyrics applied to develop speaking skill. Keeping rhythm and patterns of sound can be taught. In developing language and literacy, music presents a terrific role (Woodall \& Ziembroski 2002, p. 1). The use of song facilitates learning process by reducing pressure. The state of affective depends on apprehensible degree of receptivity. It appoints to students' emotional of exposure to the language input.

Song is expressive, conveys love and emotion, tells a memorable story, realizes the dream, and reminds the past. To echo in the learner's heart, a song has plentiful in themes and expressions. Bolitho et al., (2003) state that song is "meaningful and repeated exposure to comprehensible input affect language acquisition” (p. 253).

\section{Methodology}

This study belongs to experimental research. It concerns studying the effect of specified and controlled treatments given to the subjects belonging to different groups. The sampling technique shows the procedure, the researcher adopted in selecting items to the selection process which is known sampling technique (Kothari, 2004, p. 55). The sampling technique applied to take the representative sample from the population in this study was random cluster sampling. The sample took two classes from twenty-seven classes in the fourth semester of 'Aisyiyah health Sciences college of Yogyakarta in the academic year 2013-2014. The researcher picked the class observation randomly. First, the researcher chose one to three classes randomly. The second step was taking the first out was experimental, and the second out was the control group. Thus, the selected classes were English $4 . \mathrm{B} 2$ as an Experimental group and English 4.A1 as a Control group. 
Table 1. The sample of the Physiotherapy Class

\begin{tabular}{l|l|l|l} 
No. & Class & Students & Subject of study \\
\hline 1 & Nursing 4.B2 & 21 & $\begin{array}{l}\text { The experimental } \\
\text { group (using songs) }\end{array}$ \\
\hline 2 & $\begin{array}{l}\text { Physiotherapy } \\
\text { 4.A1 }\end{array}$ & 20 & $\begin{array}{l}\text { The control group } \\
\text { (without using songs) }\end{array}$
\end{tabular}

The samples in this research were Nursing English class 4.B2 which had 21 students as the experimental group and physiotherapy English class 4.A1 which had 20 students as the control group.

This study applied a test as the research instrument. According to (Suharsimi, 2010: 32), a test needs for people in or group of people to be held to measure the skill, intelligence, or ability. There were two types of test, i.e., pre-test and post-test. The pre-test was conducted to know how far the students' speaking ability before treatment. The posttest was conducted to find out how far the treatment had influenced the students' speaking ability. The instrument used in this research was a speaking test.

The researcher scored the test result using these categories based on Hughes, et al. (2003, pp. 131-133) below:

Table 2. Proficiency Descriptions

\begin{tabular}{|c|c|c|c|}
\hline No & $\begin{array}{l}\text { The Aspect } \\
\text { Evaluated }\end{array}$ & Score & Criterion \\
\hline 1. & Dialect/Accent & $\begin{array}{l}1 \\
2 \\
3 \\
4 \\
5 \\
6\end{array}$ & $\begin{array}{l}\text { Inexplicable Pronunciation. } \\
\text { Bold accent is difficult to understand. } \\
\text { Foreign accent takes strong listening, and } \\
\text { mispronunciation leads to stray misunderstanding and } \\
\text { grammar or vocabulary mistakes. } \\
\text { Marked foreign accent and mispronunciation that do } \\
\text { not obstruct understanding. } \\
\text { Have no striking mispronunciation yet would not be } \\
\text { brought to foreign accent. } \\
\text { Have native pronunciation }\end{array}$ \\
\hline 2. & Grammar & $\begin{array}{l}1 \\
2\end{array}$ & $\begin{array}{l}\text { Slipshod grammar. } \\
\text { Have errors of very few major patterns and avoiding }\end{array}$ \\
\hline
\end{tabular}




\begin{tabular}{|c|c|c|c|}
\hline No & $\begin{array}{l}\text { The Aspect } \\
\text { Evaluated }\end{array}$ & Score & Criterion \\
\hline & & $\begin{array}{l}5 \\
6\end{array}$ & $\begin{array}{l}\text { communication. } \\
\text { Have errors showing similar patterns and causing } \\
\text { occasional misunderstanding. } \\
\text { Stray errors showing imperfect patterns, yet it is not a } \\
\text { weakness that leads to misunderstanding. } \\
\text { Few errors and have no failure patterns. } \\
\text { No more than two errors during the interview. }\end{array}$ \\
\hline 3. & Vocabulary & $\begin{array}{l}1 \\
2 \\
3\end{array}$ & $\begin{array}{l}\text { Insufficient vocabulary in simple sentence. } \\
\text { Limited vocabulary to basic knowledge. } \\
\text { Have several inaccurate words and vocabulary } \\
\text { limitation in several comments. } \\
\text { Have vocabulary to discuss interests, general } \\
\text { vocabulary in discussion with some circumlocutions. } \\
\text { Have vocabulary broad and precise; make sentences } \\
\text { with complex practical and varied situations. } \\
\text { Vocabulary as accurate and comprehensive like a } \\
\text { native speaker. }\end{array}$ \\
\hline 4. & Fluency & $\begin{array}{l}5 \\
6\end{array}$ & $\begin{array}{l}\text { Have hesitant speech and have an incomplete } \\
\text { conversation. } \\
\text { Have more pacing and pausing for even long or short } \\
\text { sentences. } \\
\text { Speech is often halting sentences, sometimes have } \\
\text { meager sentences. } \\
\text { Have occasionally hesitant of speech, with some } \\
\text { unevenness by rephrasing words. } \\
\text { Have forceless and smooth speech. } \\
\text { Have fluent, effortless, and clear Speech as a native } \\
\text { speaker. }\end{array}$ \\
\hline 5. & Comprehension & $\begin{array}{l}1 \\
2\end{array}$ & $\begin{array}{l}\text { Comprehend little for short conversation. } \\
\text { Understand and answer slowly; have a short speech on } \\
\text { common topics. } \\
\text { Conceive simplified in dialogue but have substantial } \\
\text { repetition and rephrasing. } \\
\text { Understand carefully educated speech in dialogue but } \\
\text { have an occasional recurrence. } \\
\text { Understand everything in conversation except for } \\
\text { speak unclearly. } \\
\text { Understand in formal and informal speech to be } \\
\text { expected as a native speaker. }\end{array}$ \\
\hline
\end{tabular}

\section{Data Collecting Technique}

In this research, there are many ways to collect the data. According to Suharsimi (2010), there are some data collecting questioner, observation, and documentation (p. 126). To obtain the data, in the speaking test, the researcher applied testing.

methods to the data collecting, i.e., testing, 
In collecting the data, there are three steps which are conducted by the researcher, i.e., pre-test, performing treatment, and posttest.

\section{Giving Pre-test}

Creswell (2008) states that pre-test makes a specific measurement that evaluates the participant in before having a treatment (p. 301). The researcher conducted pre-test by giving a test to both groups; the experimental group (Nursing English class 4.B2) and the control group (physiotherapy English class 4.A1). The form of the test was an open question at least five questions in speaking. It needs 90 minutes to complete it. The material was chosen based on daily activity; (future activity). The pre-test was done to measure the speaking ability of the student before conducting the treatment. The researcher administered the test at the beginning of the research.

\section{Giving Treatment}

There was treatment after pre-test. The researcher conducted the treatment in 8 meetings. The treatment applied songs for teaching speaking. The researcher used songs as the treatment in the experimental class $4 . \mathrm{B} 2$ for teaching speaking. Meanwhile, in the control class 4.A1, the researcher taught speaking without song as the treatment.

\section{Giving Post-Test}

The post-test is a specific measurement that evaluates the participant in after having a treatment (Creswell, 2008, p. 301). It is to know the speaking ability after getting the treatments to measure the differences in the speaking ability of students. The researcher then saw the effect of the treatments given during the treatment process. Then, the researcher gave the post-test to both groups. It had three steps in data collection, such as pre-test, treatment, and post-test.

\section{The Instrument Validity and Reliability}

The instrument can be applied to get the data of the research before the test of validity and reliability. To find out the applicable instruments, the researcher tested in the tryout and gave it to respondents out of the research (respondents included in experimental and control group). The researcher applied the try-out result to verify the validity and reliability of the instrument.

1. Validity

Validity is the instrument extension to measures what it is supposed to measure (Nurgiantoro, 2004, p. 336). Item validity was implied to find out the correlation between the total score to each item and the overall test score. The 
technique to analyze the quality as the validity of the test is a coefficient of Point Biserial. The formula that is used to know the item validity is the correlation formula:

$r_{p b i}$
$\frac{\overline{x p}-\overline{x \boldsymbol{q}}}{\boldsymbol{S D}} \sqrt{\boldsymbol{p q}}$

Where:

$r_{p b i}=$ Coefficient of Point Biserial

$\overline{x p}=$ The score mean for right answering item

$\overline{x q}=$ The score mean for wrong answering item

$\mathrm{SD}=$ The Standard Deviation $\mathrm{p}=$ The student proportion for right answering item

$\mathrm{q}=$ The student proportion for incorrect answering item

2. Reliability

A test cannot measure anything well unless it is measured consistently. In this study uses the KR-21 formula (Kuder Richardson).

$$
r_{11}=\frac{k}{k-1}\left\{1-\frac{\bar{x}(k-\bar{x})}{k \cdot S D^{2}}\right\}
$$

Where:

$r \quad=$ The test reliability

$\mathrm{k} \quad=$ Items number

$\mathrm{x}=$ Total mean of score

$\mathrm{SD}=$ Standard deviation

Table 3. The Value of the Reliability Coefficient

\begin{tabular}{c|c|c} 
No. & The Coefficient of Reliability & Category \\
\hline 1. & $0.800-1000$ & Very High \\
\hline 2. & $0.600-0.790$ & High \\
\hline 3. & $0.400-0.599$ & Average \\
\hline 4. & $0.200-0.399$ & Low \\
\hline 5. & $0.000-0.199$ & Very Low
\end{tabular}

\section{Result and Reinforcement}

The test was conducted to collect data. categories; 8 students (38.1\%) poor, 13 The researcher implied an interview to students $(61.9 \%)$ very poor, and none $(0 \%)$ measure the speaking ability of the students. to fair, good and very good. The students in From the frequency distribution of the control group pre-test, the researcher, found students in the Experimental pre-test, the the results in some categories; 4 students researcher found the results in several 
(20\%) poor, 16 students (80\%) very poor, and none $(0 \%)$ to fair, good and very good.

The researcher conducted the treatment in eight meetings and used as the treatment in the experimental group. Meanwhile, the researcher taught speaking without songs as the treatment in the control group. The learning process passed in three steps, namely, pre-test, treatment, and post-test. In the pre-test, the researcher gave several questions to stimulate students' during the class. The treatment included the following kind of techniques: songs by $\mathrm{mp}$, comprehend songs, missing lyrics exercises, and oral composition. Meanwhile, the main activity of teaching speaking without using songs included as follows; doing the exercises in the students' guidebook, speaking assignment, and homework. Summarizing and evaluating was given in the post-test.

Based on the frequency distribution of the experimental post-test, the researcher found 0 students $(0 \%)$ in the very good and very poor category, 2 students (9.5\%) in the good category, and $18(85.7 \%)$ belong to fair and 1 student $(4.8 \%)$ in the poor category. In the control group post-test, the researcher found 0 students (0\%) in very good and good category, 5 students (25\%) in fair category, and 12 students $(60 \%)$ in who belong to poor category, and 3 students (15\%) in who belong to very poor category.

\section{Discussion}

The findings include the test result and effectiveness. The objective of this study is to find out whether there is a difference in the speaking ability of student in the experimental and control class. Song might play a role in lexical remembrance, when melody repeats verses as the simple part of fact. This makes the student closer with the melody fast. It also translates to the text familiarity which is connected to the melody. This means that retention and lexical acquisition result from the close relation between text and its accompanying melody (Rukholm, 2015, p. 184). The teacher can clarify grammatical through lyric of song for it's easy to comprehend and to teach English.

The researcher proved these expert statements through the research held. The techniques become the factors that have a vital role in enhancing the teaching learning activity more effectively and efficiently. Therefore, teaching speaking by using songs is applicable to teaching English. It is one of the appropriate media in teaching speaking for the beginner or slow learner. The lecturer can use the songs to increase the students' speaking ability because this has the effectiveness for teaching speaking. Music can be an effective way to teach with ESL student when it is implemented intensively, and the use of song makes the efficacy in 
ESL classroom (Li \& Brand, 2009, pp. 8283).

The researcher found a statistical difference in the student speaking achievement in speaking ability between the experimental and control group. The alternative hypothesis (H1) stated in this research that was accepted, whereas the zero hypothesis (HO) was rejected. The value of (P) was lower than the level of significance $(0.001<0.05)$, so the hypothesis was stating that teaching speaking using song was more effective than teaching speaking without using song was accepted. The researcher can conclude that teaching speaking by using songs is effective.

Table 4. The Experimental and Control Group Data Description

\begin{tabular}{l|c|c|c|c}
\multirow{2}{*}{\multicolumn{1}{c|}{ Data }} & \multicolumn{2}{|c|}{ Experimental } & \multicolumn{2}{c}{ Control } \\
\cline { 2 - 5 } & $\begin{array}{l}\text { Pre- } \\
\text { test }\end{array}$ & $\begin{array}{l}\text { Post- } \\
\text { test }\end{array}$ & $\begin{array}{l}\text { Pre- } \\
\text { test }\end{array}$ & $\begin{array}{l}\text { Post- } \\
\text { test }\end{array}$ \\
\hline $\begin{array}{l}\text { Number of } \\
\text { classes (N) }\end{array}$ & 21 & 21 & 20 & 20 \\
\hline Mean (M) & 10.19 & 17.47 & 10.05 & 13.85 \\
\hline $\begin{array}{l}\text { Standard } \\
\text { Deviation (SD) }\end{array}$ & 2.421 & 2.064 & 1.877 & 2.601 \\
\hline Maximal Score & 15.00 & 23.00 & 15.00 & 20.00 \\
\hline Minimal Score & 7.00 & 14.00 & 7.00 & 11.00
\end{tabular}

\section{Conclusion}

In conclusion, there is a significative difference in the speaking ability between teaching speaking by song and teaching speaking without a song. The data show that post-test mean in the experimental group $(17.47)$ is higher than the post-test mean in the control group (13.85). It has advantages in developing students' speaking ability by using songs.

The suggestion is hopefully a great use to improve English teaching, especially in
English speaking skill. There are some recommendations; (1) Using songs in teaching can give benefit to develop students' speaking ability. Thus, the facilitator is suggested to apply media songs in the English teaching and learning process. (2) The researcher suggests other researches to design a similar topic of study or to develop other skill. The researcher wishes that this article will help guide and stimulate additional research on teaching English. 


\section{References}

Bolitho, R., Carter, R., Hughes, R., Ivanic, R., Masuhara, H. \& Tomlinson, B. 2003.Ten Questions About Language Awareness. Lancaster: ELT Journal.

Brown, H. Douglas. 1994. Principles of language teaching and learning. $3^{\text {rd }}$ edition. Englewood Cliffs, NJ: Prentice-Hall Regents.

Cameron, Lynne. 2001. Teaching Language to Young Learners. Cambridge: Cambridge University Press.

Creswell, J. W. 2008. Educational Research: Planning, Conducting, and Evaluating Quantitative and Qualitative Research. Third Edition. New Jersey: Pearson Education. Ltd.

Hughes, Arthur. 2003. Testing for Language Teachers. United Kingdom: Cambridge University Press.

Luoma, S. 2008. Assessing Speaking. Cambridge. UK: Cambridge University Press.

Nunan, D. 2003. Practical English Language Teaching. New York: McGraw Hill.

Nurgiantoro. 2004. Metode Penelitian Pendidikan Pendekatan Kuantitatif,
Kualitatif, dan $R$ Eु $D$. Bandung: Alfabeta.

Schoepp, K. 2001. Reasons for Using Songs in the ESL/EFL Classroom. The Internet TESL Journal, VII(2). Retrieved 20.12. 2012 from http://iteslj. org/Articles/Schoepp-Songs. html.

Sharpe, K. 2001. Modern Foreign Languages in the Primary School: The what, why and how of Early MFL Teaching. London: Kogan Page.

Sheldon, L. K. 2004. Communication for Nurses: Talking with Patients, New Jersey: SLACK Inc.

Simpson, J. M. 2000. Practice Multiple Intelligences in EFL Class. TESOL Journal. Creative Classroom Practice. New York: Longman.

Suharsimi Arikunto. 2010. Prosedur Penelitian Suatu Pendekatan Praktik. Jakarta: Rineka Cipta.

Urrutia, W., \& Vega, E. (2006). Encouraging students to improve speaking skills through game in a colombian school. PROFILE Issues in Teacher's Professional Development, (212).

Woodall, L and Ziembroski, Brenda. 2001. Song for Teaching. London: Cambridge University Press. 